\title{
The spatial integration of paddy markets in Vietnam
}

Trung, Le Dang; Tam, Tran Ngo Minh; Baulch, Bob; Hansen, Henrik

Publication date:

2007

Document version

Publisher's PDF, also known as Version of record

Citation for published version (APA):

Trung, L. D., Tam, T. N. M., Baulch, B., \& Hansen, H. (2007). The spatial integration of paddy markets in Vietnam. Fødevareøkonomisk Institut, Københavns Universitet. IFRO Working Paper Vol. 2007 No. 13 
The Spatial Integration of Paddy Markets in Vietnam

Institute of Food and Resource Economics (FOI) Working Paper 2007/13 


\title{
The Spatial Integration of Paddy Markets in Vietnam
}

\author{
Le Dang Trung \\ Centre for Analysis and Forecasting, Vietnamese Academy of Social Sciences \\ Tran Ngo Minh Tam \\ Centre for Analysis and Forecasting, Vietnamese Academy of Social Sciences
}

Bob Baulch

Institute of Development Studies at the University of Sussex

Henrik Hansen

Institute of Food and Resource Economics, University of Copenhagen and Centre for Analysis and Forecasting, Vietnamese Academy of Social Sciences

\begin{abstract}
This paper examines whether there is spatial integration between and within paddy markets in the North and South of Vietnam. The empirical model developed uses estimates of transfer costs to generalize Ravallion's model of spatial market integration to allow for threshold effects. A sequential testing strategy is used to test for market segmentation, the number of thresholds, long-run integration, in-formational efficiency, and the 'Law' of One Price within an error-correction frame-work. We find no threshold effects and weak evidence of paddy market integration between northern and southern Vietnam. There is, however, evidence of both threshold effects and stronger market integration within the Red and Mekong River deltas. Whenever price spreads exceeds their thresholds at least 60 percent of price changes are transmitted between regional markets within a month. None-the-less, the instantaneous version of the 'Law' of One Price only holds for a few regimes and market pairs.
\end{abstract}

These results suggest that national level policies cannot be relied upon to stabilize or support paddy prices in Vietnam. Instead, policies need to be designed with the specific production, consumption and marketing characteristics of northern and southern Vietnam in mind. 
ISBN 978-87-92087-34-8 (print, The Spatial Integration of Paddy Markets in Vietnam)

ISBN 978-87-92087-35-5 (on-line, The Spatial Integration of Paddy Markets in Vietnam) 


\section{Table of contents}

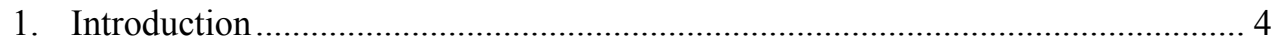

2. Paddy Production, Consumption, Marketing and the Changing Policy

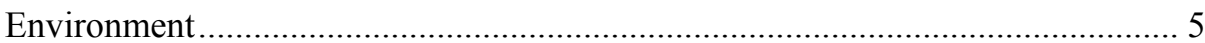

3. Modelling and Testing for Market Integration with Transfer Costs .................... 11

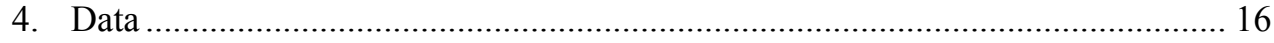

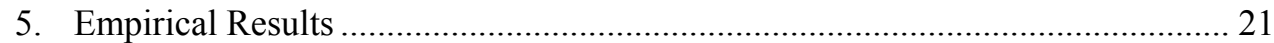

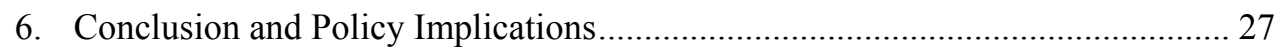

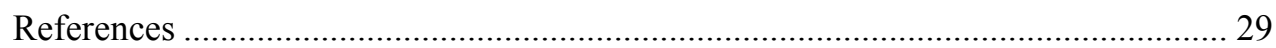

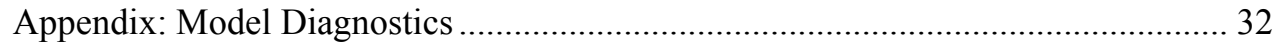




\section{Introduction}

With its increasing integration into the world economy, Vietnam's agricultural exports have grown substantially in recent years. From being a net importer of rice in the late 1980s, by the late 1990s Vietnam had become one of the largest rice exporting countries. Paddy production has grown from 23 million metric tons in 1993 to 36 million metric tons in 2005 , with 70 percent of total paddy output coming from the Red River and Mekong River deltas.

At the sub-national level, there are concerns that not all regions and categories of agricultural producers have and will benefit from the liberalization of Vietnam's agricultural markets. There are two distinct aspects to these concerns. First, if domestic markets are not spatially integrated, not all regions will benefit from market and trade liberalization to the same extent. Second, even if domestic markets are integrated in the long term, lack of integration in the short-term may mean that price changes are not transmitted between consumption centres and production areas quickly enough. If this is the case, agricultural market liberalization may disproportionately benefit traders and agricultural processors rather than agricultural producers and consumers.

Accordingly, this study aims to answer three interrelated questions. First, is there is spatial integration between paddy markets in the North and South of Vietnam? The elongated geography of Vietnam results in high transfer costs for food market transactions between the northern and the southern regions. Second, is there spatial integration in paddy markets within the North and within the South? We focus on paddy prices in the Red River Delta in the North and the Mekong River Delta in the South, both because they produce over two-thirds of national paddy output and because the price data for these regions is fairly comprehensive and complete. Finally, a third question to ask is if within-region integration is stronger and faster than betweenregion integration.

Section 2 provides an overview of paddy production, consumption and marketing in Vietnam from the 1990s to 2005 together with the key economic reforms that have occurred during this period. Section 3 describes our modelling and testing strategy, emphasizing the importance of thresholds in the presence of transfer costs. A threshold error correction model is proposed to sequentially test for different forms of market integration. Section 4 describes the monthly paddy price data used and how we have estimated transfer costs. Section 5 contains our empirical results. We find no threshold effects and weak evidence of paddy market integration between northern

\section{FOI The Spatial Integration of Paddy Markets in Vietnam}


and southern Vietnam. There is, however, evidence of both threshold effects and stronger market integration within each region. Section 6 offers some concluding remarks and policy recommendations.

\begin{tabular}{|c|c|c|c|c|c|}
\hline Year & $\begin{array}{r}\text { Agricultural land } \\
\text { (1) }\end{array}$ & $\begin{array}{r}\text { Arable land } \\
(2)\end{array}$ & $\begin{array}{r}\text { Planted area } \\
\text { of cereal } \\
(3)\end{array}$ & $\begin{array}{r}\text { Planted area } \\
\text { of paddy } \\
(4)\end{array}$ & $\begin{array}{r}\text { (4) as percentage } \\
\text { of (3) } \\
(5)\end{array}$ \\
\hline 1993 & 7087 & 5516 & 7058 & 6559 & 92.93 \\
\hline 1994 & 7140 & 5464 & 7136 & 6599 & 92.47 \\
\hline 1995 & 7079 & 5403 & 7324 & 6766 & 92.37 \\
\hline 1996 & 7682 & 5554 & 7621 & 7004 & 91.91 \\
\hline 1997 & 7844 & 5668 & 7768 & 7100 & 91.39 \\
\hline 1998 & 8055 & 5763 & 8016 & 7363 & 91.85 \\
\hline 1999 & 8413 & 6000 & 8349 & 7654 & 91.68 \\
\hline 2000 & 8780 & 6200 & 8399 & 7666 & 91.28 \\
\hline 2001 & 9483 & 6649 & 8225 & 7493 & 91.10 \\
\hline 2002 & 9455 & 6600 & 8323 & 7504 & 90.17 \\
\hline 2003 & 9622 & 6680 & 8367 & 7452 & 89.07 \\
\hline 2004 & n.a & n.a & 8438 & 7445 & 88.24 \\
\hline 2005 (prel.) & n.a & n.a & 8371 & 7326 & 87.52 \\
\hline
\end{tabular}

Source: GS0 (2006).

\section{Paddy Production, Consumption, Marketing and the Changing Policy Environment}

About two thirds of Vietnamese farm households grow paddy to serve the high domestic demand for rice, exclusive of exporting requirement. Roughly 53 percent of Vietnam's agricultural land area, which is approximately 4 million hectares, is devoted to the growing of paddy (Minot and Golleti, 1999; FAOSTAT, 2006). Benjamin and Brandt (2004) summarize the state of Vietnamese paddy production as: "Rice production in Viet Nam is characterized by small irrigated farms, multiple cropping, labour intensive practices, and growing use of inorganic fertilizer, though there are substantial regional differences". Although the planted area of paddy increased from 7357 to 7444 thousand hectares, its share of total planted area has been declining (Table 1).

The seasons for paddy growing vary across regions. In the North, there are generally two paddy crops annually: the Winter-Spring and Summer-Autumn crops. In irrigated areas in the South, there are usually three paddy crops per year: the Summer-Autumn, Autumn-Winter and Winter-Spring crops (Minot and Golleti, 1999; Luu, 2003). In rainfed areas in the South, only a wet-season crop is produced in the Autumn-Winter. 
Figure 1. Paddy production by season in 1995-2005

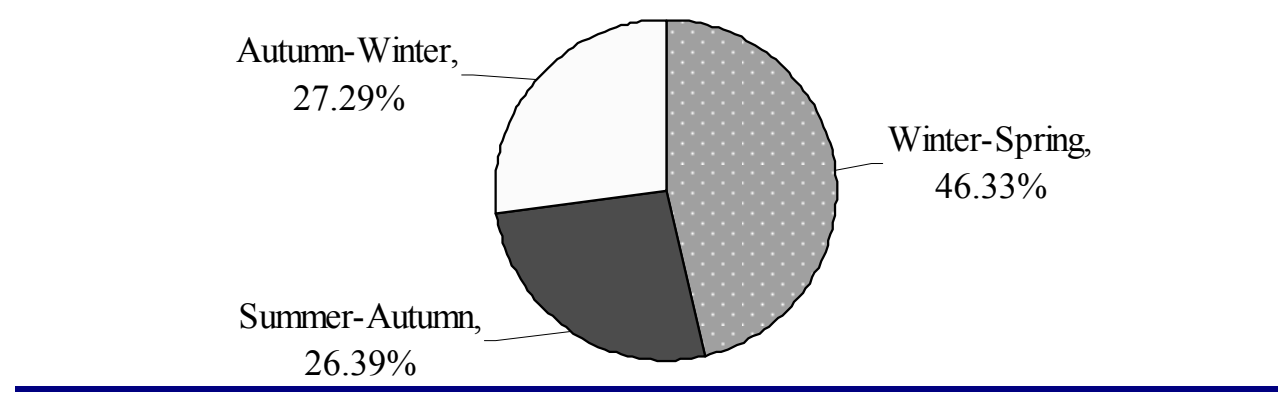

Source: GSO (2006)

Note: Figures for 2005 are preliminary

By producing three crops staggered across the year, Vietnamese farmers can supply paddy to the market almost continuously through-out the year. Nationally, the WinterSpring crop accounts for just below one-half of paddy production while the SummerAutumn and Autumn-Winter crops each ac-count for just over one-quarter (Figure 1).

There are a wide range of paddy varieties grown in Vietnam, but modern high yielding varieties dominate production in irrigated areas and are also widely used for the wet-season crop in rainfed areas. The percentage of paddy area planted to modern varieties increased from $47.5 \%$ in 1990 to almost $90 \%$ in 2000 (Tran, 2002). Adoption rates are believed to now exceed 95\% (Centre for Agricultural Policy, 2007). Use of modern varieties is slightly higher in the North than the South of Vietnam. Traders usually classify paddy production into two grades: lua dai (long grain or C1) and lua tron (medium short grain or C2), which is also know as ordinary paddy (Luu, 2003). In this paper, we focus on the more widely traded ordinary grade of paddy.

The period since the early 1990s had been one of dramatic but gradual economic change in Vietnam. Since the introduction of the Doi moi (economic renovation) reforms in late 1986, Vietnam has been gradually moving to a market-oriented economy. Key changes that have affected the agricultural sector in general, and paddy producers and markets in particular, include:

- $\quad$ The extension of land use rights to most farmers through Resolution 5 of 1988 and the Land Laws 1993 and 2003. By guaranteed paddy farmers' tenure for 20 or more years for annual crop land giving them the right to exchange, trans-

6 FOI The Spatial Integration of Paddy Markets in Vietnam 
fer, lease, inherit and mortgage their land, these land reforms have improved incentives for cultivation (Minot and Goletti, 1999);

- The liberalization of rice and fertilizer marketing starting with the reduction of tariff on rice export from ten to one percent in 1991. This was followed by extension of authority to import fertilizer from central to provincial State-Owned Enterprises, the gradual lifting of the rice export quota, from less than 1 million ton in 1992 to 4.5 million tons in 1998, the loosening of internal barriers to trading rice between Northern and South in 1997, and the abolition of quotas on rice export and fertilizer import in 2001 (Benjamin and Brandt, 2004).

- The declaration of a Water Law in 1999, which established a system of licenses and permits to allocate water, followed by the founding of a National Water Resources Council and basin-level committees was set-up to manage and allocate water in the Red River Delta, Mekong River Delta and other areas. These reforms to the water system facilitated the intensification of cropping from one to two or three paddy crops per year (Barker, et al., 2004).

In addition, a gradual improvement of road and market infrastructure has generally improved the trading environment. Such changes have not, however, necessarily lead to a reduction in transfer costs, as freight rates are controlled by the State Pricing Committee and have remained stable in nominal terms since 1997. ${ }^{1}$ In addition, our interviews with traders and transporters (see Section 4) indicate that savings in vehicle operating costs, due to the gradual improvement of the road system, have been largely offset by higher road and bridge tolls plus charges on trucks entering large municipal areas.

Vietnam's paddy production has been rising continuously during 1995-2005 with an average annual growth rate of 3.7 percent (Figure 2). In addition to the enhanced incentives provided by the market liberalization measures described above, this growth is attributed to an increase of 2.9 percent in yield of paddy (productivity) and the weak expansion of planted areas devoted to paddy, at the rate of about 0.8 percent per annum (Minot and Goletti, 1999).

${ }^{1}$ See State Pricing Committee Decision 36 of 1997 and Decision 89 of 2000. 
Figure 2. Paddy production by region, 1995-2005

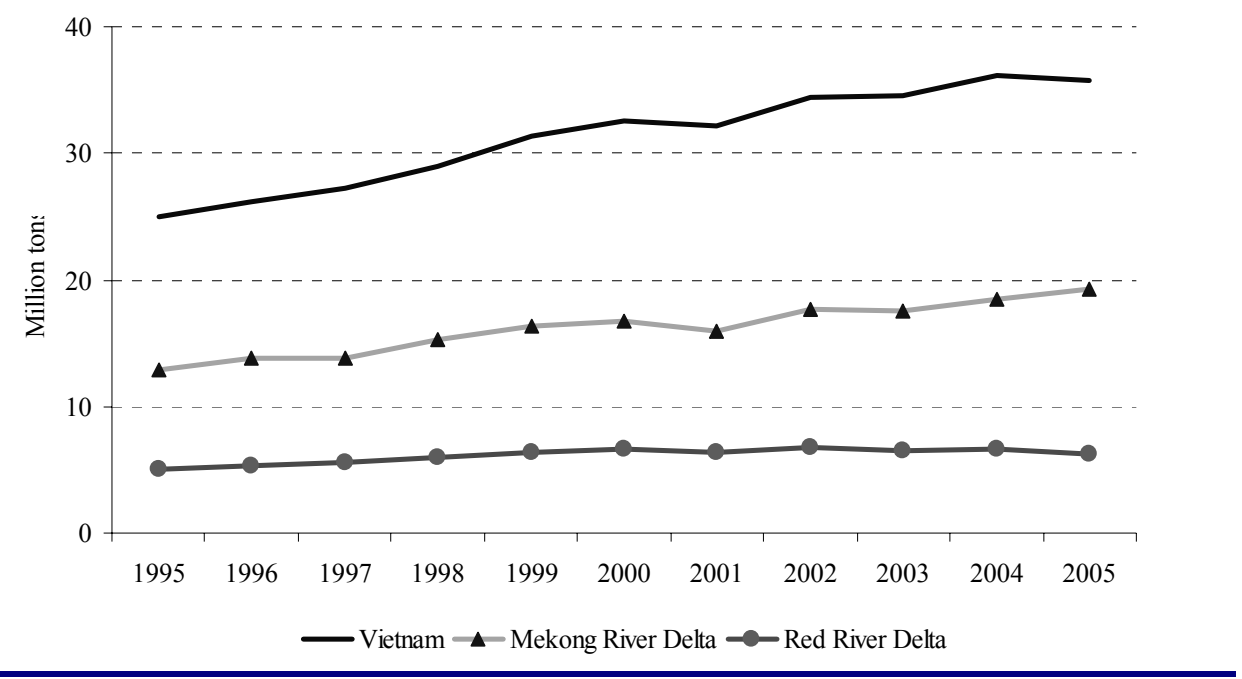

Source: GSO (2006).

Note: Figures for 2005 are preliminary

Vietnam has two main granaries: the Mekong River Delta in the South and the Red River Delta in the North. These two deltas, which account for 42.5 percent of the population, supply rice to the remaining five regions. The Mekong River Delta, the so-called "rice bowl of Vietnam", supply more than a half (52 percent) of national paddy output, followed by the Red River Delta that produces around 20 per-cent of the total. None of the other five regions individually accounts for more than 9 percent of national paddy production.

Rice is the main staple in the Vietnamese diet. About 83 percent of total annual paddy production is consumed domestically while the other 17 percent is exported. FAO Balance Sheets indicates that the main portion of domestic consumption (about 84 percent) is used for food, with the remaining 16 percent accounted for by waste, seed and feed. Since the mid 1990s, Vietnam has become a major rice exporting country, with the volume of rice exports rising from 2 million tons in 1995 to 5.3 million tons in 2005 (Figure 3). In terms of volumes, Vietnam is now the second largest rice exporter in the world after Thailand. However, in terms of value, Vietnam's rice exports rank fourth or fifth in the world market due to the low quality of its rice exports and the limited value-added to paddy.

\section{FOI The Spatial Integration of Paddy Markets in Vietnam}


Figure 3. Vietnam's export of rice in paddy equivalent

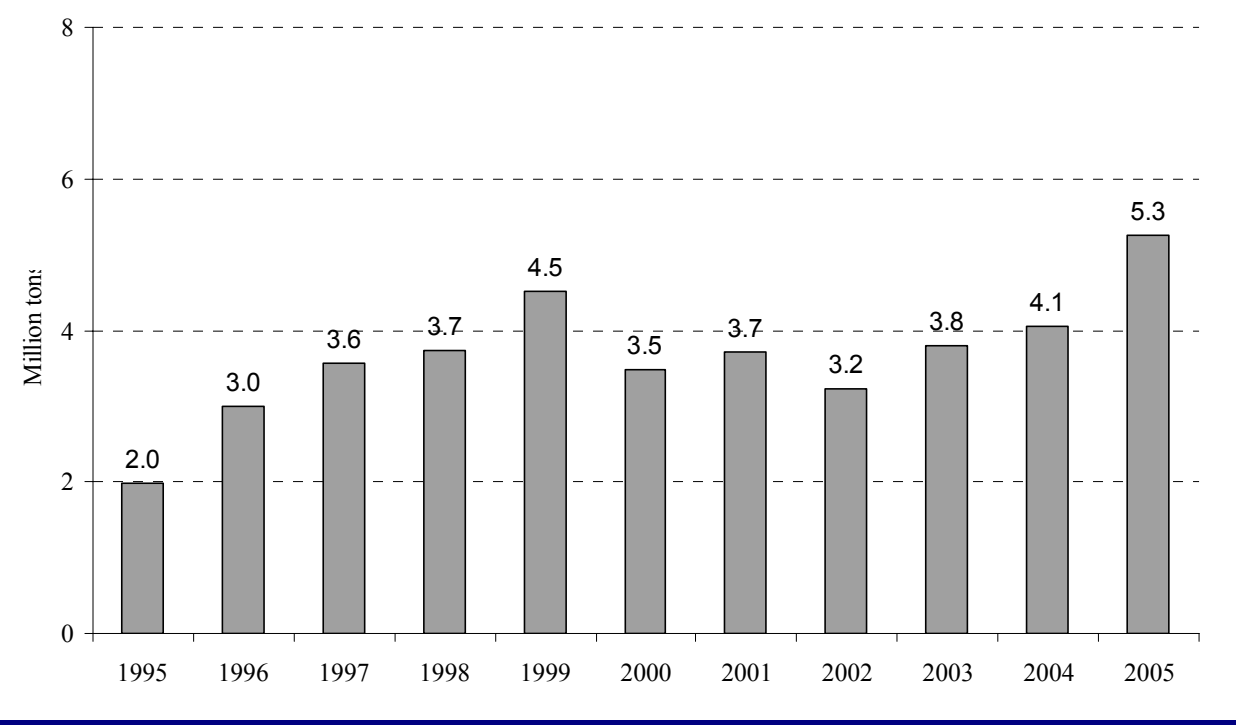

Source: GSO (2006)

Note: Figures for 2005 are preliminary

Before sale to consumers as milled rice, paddy goes through a process that involves many stages, including checking and sorting, drying and storing, milling, polishing and packaging, storage and transportation (Luu, 2003). There are various channels used for marketing paddy and rice in Vietnam (Figure 4). According to Minot and Goletti (1999), more than two-thirds of paddy is sold to the assemblers, of whom 95 percent are private firms. Most of the remainder goes to small-scale millers for farmers' home consumption, while a small share is bought directly by larger millers. The assemblers then either have the paddy custom milled or sell paddy to medium and large-scale millers. Most mills are located with 30 kilometre radius of the production areas in which these assemblers operate (Luu, 2003). The assemblers and millers sell the milled rice on to the wholesalers and retailers. State-Owned Enterprises (SOEs) play a relatively minor role in the within province marketing of paddy and rice but control the long-distance trade and the rice export market. SOEs consist of provincial and regional food companies (of which Vinafood I in the North, and Vinafood II in the South are the most important). 
Figure 4. Vietnam's paddy and rice marketing channels

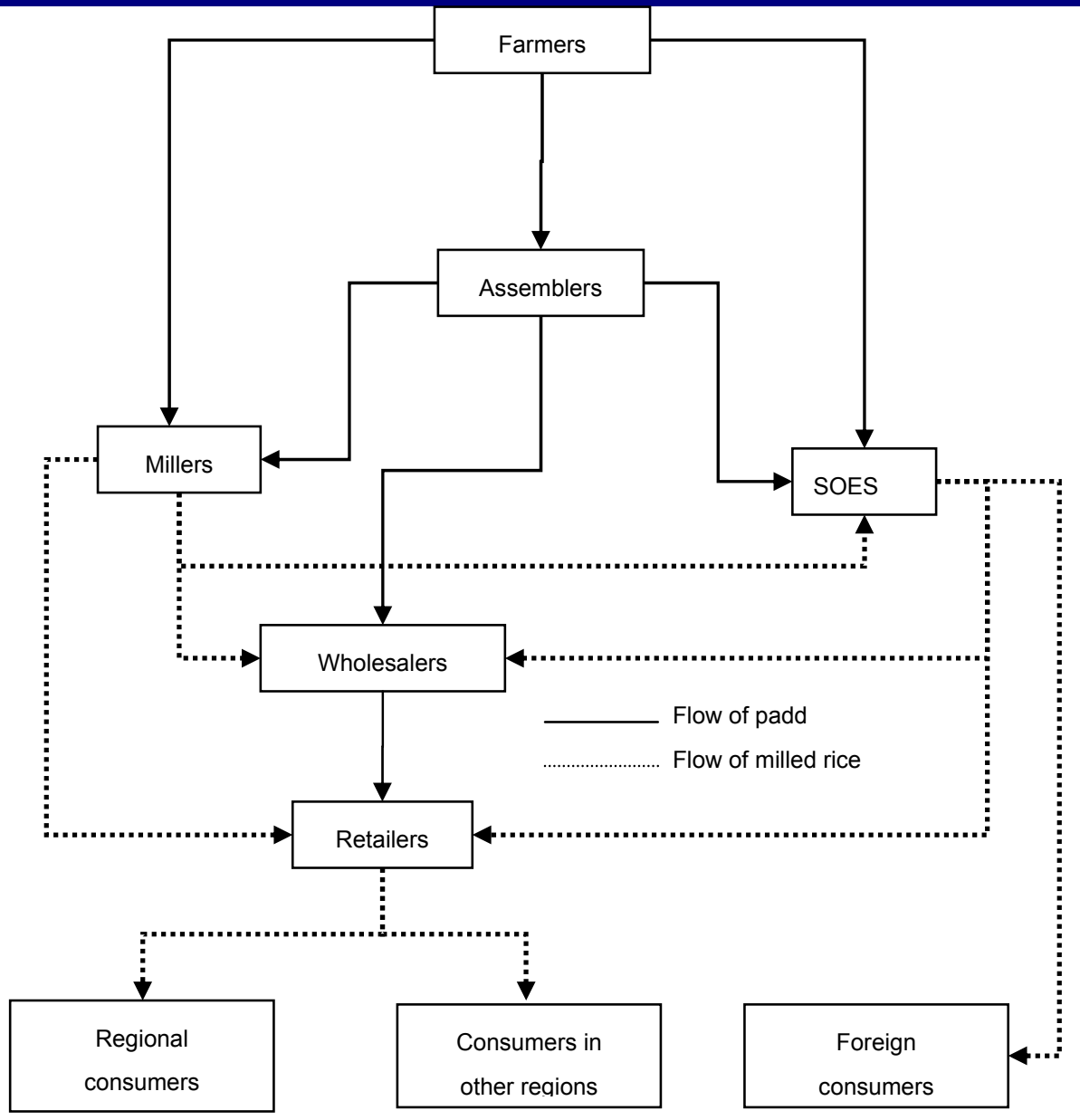

Source: Drawn by the authors, based on Luu (2003) and Minot and Golletti (1999)

10 FOI The Spatial Integration of Paddy Markets in Vietnam 


\section{Modelling and Testing for Market Integration with Transfer Costs}

Tests of spatial market integration using time series data on food prices date back to the 1960s. ${ }^{2}$ The first tests arose from Lele's (1967) and Jones' (1968) analyses of staple food prices in India and Nigeria, respectively. The two authors estimated the contemporaneous correlations between price series in two markets in different locations. When the correlations were greater than 0.7 or 0.8 , they concluded that price movements were close enough for the two markets to be considered as being spatially integrated. The cut-off point used for deciding if markets were spatially integrated was, however, arbitrary and no consideration was given to whether or not the price series were stationary or non-stationary. Nonetheless, many of the subsequent econometric models used for testing spatial market integration rely on the same idea of testing how closely prices move together. In particular, models of the Law of One Price (Isard, 1977; Richardson, 1978) and the Ravallion model (Ravallion, 1986) are both extensions of the correlation idea. Cointegration tests have also been used to test for the comovement of food prices and long-run market integration (Alexander and Wyeth, 1991; Dawson and Dey, 2002).

A growing body of the spatial market integration literature stresses the importance of transfer costs. Basically, transfer costs introduce a wedge between prices at separate locations, resulting in a non-linear relationship between such pairs of prices. The parity bounds model developed by Sexton, Kling and Carman (1991) and Baulch (1997) explicitly take account of the non-linear price relationship in spatially distributed markets that is caused by transfer costs. Furthermore, much recent research focuses on an explicit modelling of threshold effects when testing the Law of One Price. See, for example, Goodwin and Piggott (2001), Meyer (2004), and Sarno, Taylor and Chowdhury (2004). ${ }^{3}$

Transfer costs are important for modelling spatial market integration as they imply a potential bias in estimators based on linear models. Consider, for example, a relationship between two paddy markets, $i$ and $j$. In the absence of transfer costs, spatial market integration will imply that the paddy prices in the two markets should be equal, so $p_{i}=p_{j}$. In Figure 5 such a market integration situation is illustrated by the 45-degree line. Now, if there are transfer costs of $t c$ per kilogram of paddy, there need

\footnotetext{
${ }^{2}$ See Fackler and Goodwin (2001) for an excellent review of these and other spatial price analysis methods.

${ }^{3}$ See Hansen $(1996,1997)$ for a general estimation procedure for threshold models.
} 
not be any trade between the markets when $p_{j}-t c<p_{i}<p_{j}+t c$ because the transfer costs make inter-market trade unprofitable. This "no trade" region suggests that prices respond differently in the three regimes defined by the upper and lower thresholds, $p_{j}$ $+t c, p_{j}-t c$. If $p_{i}$ is above $p_{j}+t c$ (for example, point $\mathrm{A}$ in Figure 5) one would expect a trade flow from market $j$ to market $i$, leading to a price increase in market $j$ and a price decrease in market $i$. Likewise, if $p_{i}$ is less that $p_{j}-t c$ (for example, point $\mathrm{B}$ in Figure 5) trade between the markets should lead to a price decrease in market $j$ and a price increase in market $i$. However, prices will only adjust when trade is profitable. When $p_{i}$ is between the $p_{j}-t c$ and $p_{j}+t c$ lines in Figure 5 (for example, point $\mathrm{C}$ ), there is no trade inducing market forces to equate the paddy prices in the two markets. We describe this as the no-trade regime. It follows that the overall correlation between the prices may be low if prices are often in this no-trade regime.

\section{Figure 5. Prices in two markets with transfer costs}

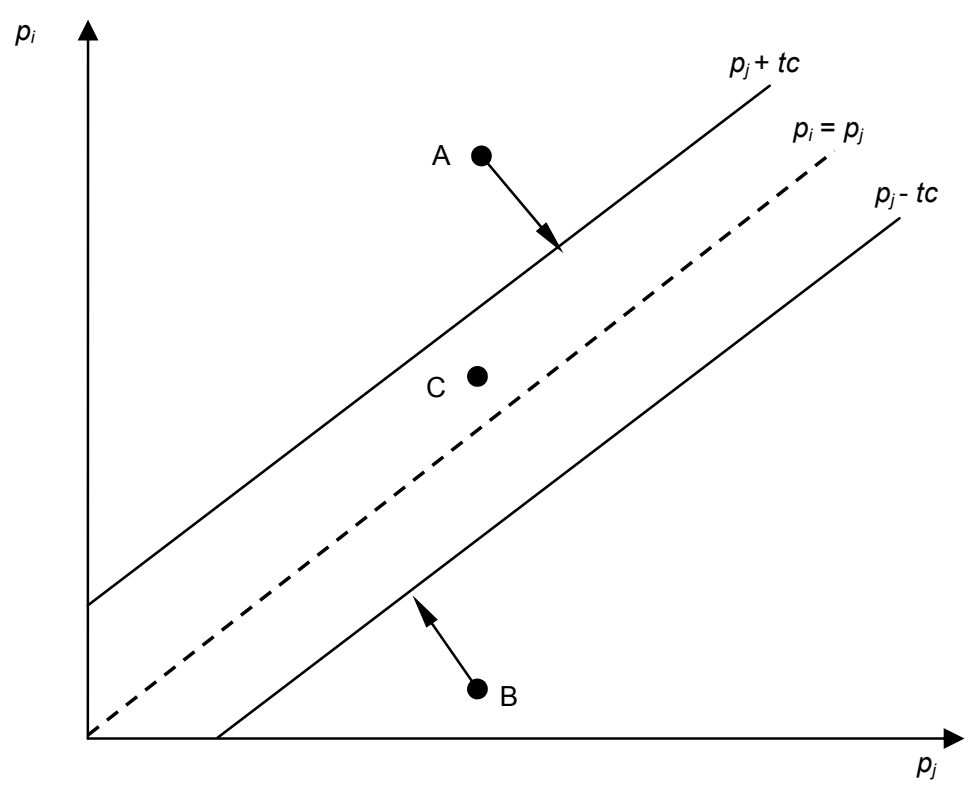

In this paper we use outside information on transfer costs to formulate a threshold variation of Ravallion's well-known dynamic model of spatial market integration (Ravallion, 1986). Specifically, we use fixed and known threshold values computed from additional information (collected from traders and transporters) about transfer

12 FOI The Spatial Integration of Paddy Markets in Vietnam 
costs to model the three regimes described above. The remainder of this section shows how the model is formulated and presents the testing sequence we use to analyze the various forms of spatial market integration.

Consider Ravallion's model of market integration in which price in market $i\left(p_{i t}\right)$ is conditional on the price in market $j\left(p_{j t}\right)$, lagged prices $\left(p_{i t-k}\right.$ and $\left.p_{j t-k}\right)$ and a set of seasonal dummies $\left(S_{t}\right):^{4}$

$$
p_{i t}=d+a_{1} p_{i t-1}+a_{2} p_{i t-2}+b_{0} p_{j t}+b_{1} p_{j t-1}+b_{2} p_{j t-2}+\phi^{\prime} S_{t}+\varepsilon_{t} .
$$

We generalize this model by allowing the constant, the autoregressive parameters and the distributed lag parameters to vary across regimes in the following way:

$$
p_{i t}=d^{(s)}+a_{1}^{(s)} p_{i t-1}+a_{2}^{(s)} p_{i t-2}+b_{0}^{(s)} p_{j t}+b_{1}^{(s)} p_{j t-1}+b_{2}^{(s)} p_{j t-2}+\phi^{\prime} S_{t}+\varepsilon_{t},
$$

in which $\theta^{(s)}=\left(d^{(s)}, a_{1}^{(s)}, a_{2}^{(s)}, b_{0}^{(s)}, b_{1}^{(s)}, b_{2}^{(s)}\right)$ are regime dependent parameters defined by

$$
\theta^{(s)}= \begin{cases}\theta^{(1)} & \text { if }\left(p_{i t-l}-p_{j t-l}\right) \geq t c_{1} \\ \theta^{(0)} & \text { if } t c_{2}<\left(p_{i t-l}-p_{j t-l}\right)<t c_{1} \\ \theta^{(2)} & \text { if } t c_{2} \leq\left(p_{i t-l}-p_{j t-l}\right)\end{cases}
$$

where the relationship between the inter-market price spread at lag $l$ and the transfer costs $\left(t c_{l}, t c_{2}\right)$ determines the regime. We refer to the 'middle' regime $\left(\theta^{(0)}\right)$ as the notrade regime, while the two 'outer' regimes are denoted the above threshold regime $\left(\theta^{(1)}\right)$ and the below threshold regime $\left(\theta^{(2)}\right)$, respectively.

For simplicity, we assume the additive seasonal component in the price series is the same in all three regimes, and also that the innovations are $\operatorname{iid}\left(0, \sigma^{2}\right)$ across the regimes. The assumption of regime independent seasonal components is made to preserve degrees of freedom as regime dependent seasonal components would add another 22 parameters to the model. The assumption of $\operatorname{iid}\left(0, \sigma^{2}\right)$ innovations is made to simplify the estimation procedure. With a constant variance across the regimes the

\footnotetext{
${ }^{4}$ An autoregressive, distributed lag model with two lags appears to give a good description of the paddy price series in the subsequent analysis. Therefore, we present the model with two lags rather than a more general model having, say, $k$ lags.
} 
model can be estimated using ordinary least squares rather than generalized least squares. ${ }^{5}$

The model in (2) can be reformulated as an error correction model allowing for nonstationary and cointegrated prices in the two markets

$$
\Delta p_{1 t}=\gamma^{(s)} \Delta p_{j t}+\delta_{1}^{(s)} \Delta p_{i t-1}+\delta_{2}^{(s)} \Delta p_{j t-1}+\alpha^{(s)}\left(p_{i t-1}-\beta^{(s)} p_{j t-1}-\mu^{(s)}\right)+\phi^{\prime} S_{t}+\varepsilon_{t}
$$

and the parameters in (2) and (4) are related by:

$$
\begin{aligned}
& \gamma^{(s)}=b_{0}^{(s)}, \delta_{1}^{(s)}=-a_{2}^{(s)}, \delta_{2}^{(s)}=-b_{2}^{(s)} \\
& \alpha^{(s)}=-\left(1-a_{1}^{(s)}-a_{2}^{(s)}\right), \beta^{(s)}=\frac{b_{0}^{(s)}+b_{1}^{(s)}+b_{2}^{(s)}}{1-a_{1}^{(s)}-a_{2}^{(s)}}, \mu^{(s)}=\frac{d^{(s)}}{1-a_{1}^{(s)}-a_{2}^{(s)}} .
\end{aligned}
$$

The error correction term in (4) is a "generalized" inter-market price spread $w_{t}=p_{i t}-\beta^{(s)} p_{j t}-\mu^{(s)}$, which simplifies to the standard inter-market price spread when $\beta^{(s)}=1$.

The threshold error correction in equation (4) can be used to test most of the interesting hypotheses about spatial market integration including the Law of One Price and Ravallion's tests for market segmentation and long-run market integration. ${ }^{6}$ The first hypothesis to be tested is one of market segmentation. Based on Ravallion (1986), we define market segmentation as a model in which the price in market $j$ does not Granger-cause the price in market $i$ and, in addition, that there is no instantaneous correlation between the price series - in any regime. Hence, in terms of parameter restrictions we say that the markets are segmented if in equation (4):

$$
H_{0}^{(1)}: \alpha^{(s)}=0, \delta_{2}^{(s)}=0, \gamma^{(s)}=0, \quad \text { for all } s=0,1,2 .
$$

If market segmentation is rejected, we next test for the number of thresholds. This is done in three steps. Specifically, we formulate and test the three hypotheses

$$
H_{0}^{(2 a)}: \theta^{(1)}=\theta^{(0)}, \quad H_{0}^{(2 b)}: \theta^{(2)}=\theta^{(0)}, \quad H_{0}^{(2 c)}: \theta^{(1)}=\theta^{(2)}=\theta^{(0)} .
$$

\footnotetext{
${ }^{5}$ These simplifying assumptions are made with a view to the empirical models. In the Appendix we show that the error variance is indeed constant across regimes in our estimated models and, further, that the additive seasonal components are not significantly different across regimes.

${ }^{6}$ To ensure valid inference we also test for stationarity of the individual price series.
}

14 FOI The Spatial Integration of Paddy Markets in Vietnam 
If the first two hypotheses are rejected we infer that there are two thresholds. In contrast, if all three hypotheses are accepted we infer that the model is linear.

Once the number of thresholds is established, we can further reformulate the error correction model to allow for freely varying long-run parameters in each regime

$$
\Delta p_{i t}=\gamma^{(s)} \Delta p_{j t}+\delta_{1}^{(s)} \Delta p_{i t-1}+\delta_{2}^{(s)} \Delta p_{j t-1}+\alpha^{(s)} p_{i t-1}+\pi^{(s)} p_{j t-1}+d^{(s)}+\phi^{\prime} S_{t}+\varepsilon_{t}
$$

Subsequently, we test for long-run market integration, which is the hypothesis

$$
H_{0}^{(3)}: \alpha^{(s)}=-\pi^{(s)}
$$

in equation (8). This is equivalent to testing $\beta^{(s)}=1$ in equation (4). Clearly, the number of hypotheses tested depends on the number of thresholds, so our tests for longrun market integration are regime dependent. Note that with two thresholds, the information about the long run parameters may be weak in particular in the no-trade regime. $^{7}$

If long run integration is accepted in a regime, we impose the restriction by using the lagged inter-market price spread as the error correction term (i.e., $\alpha^{(s)} p_{i t-1}+\pi^{(s)} p_{j t-1}$ is replaced by $\alpha^{(s)}\left(p_{i t-1}-p_{j t-1}\right)$ in equation(8)). If long-run market integration is rejected it makes little sense to carry on testing stronger versions of the Law of One Price. Hence, the following hypotheses and tests are only reported if the hypothesis of long-run market integration is accepted in at least one regime.

Before testing for the strong version of the Law of One Price we look at a weaker restriction, which is akin to the weak market efficiency hypothesis in the financial markets literature. This is done by formulating a hypothesis of common dynamics. We define common dynamics to be the restriction

$$
H_{0}^{(4)}: \delta_{1}^{(s)}=-\delta_{2}^{(s)}
$$

If the hypothesis is accepted, the only past information needed to predict the price in market $i$ is the inter-market price spread in previous periods. Adding information on

\footnotetext{
${ }^{7}$ The term 'long-run market integration' may be somewhat misleading in this model as acceptance of the hypothesis in some regimes does not imply that prices will eventually be equal in the absence of shocks. However, if the hypothesis is accepted in all regimes, then the standard notion of longrun market integration applies.
} 
past values of individual prices will not improve the prediction of the price in market $i$.

Finally, given acceptance of long-run market integration and common dynamics it is interesting to test for the strong version of the Law of One Price. The hypothesis is formulated as

$$
H_{0}^{(5)}: \gamma^{(s)}=1 \text { and } \delta_{1}^{(s)}=-\delta_{2}^{(s)} .
$$

This involves testing jointly that the prices in the two markets have common dynamics and that the conditional correlation between the two prices is one. In this case, a unit change in prices in market $j$ will be associated with a one unit change in prices in market $i$ within the current time period. This is similar to Ravallion's (1986) test for short-run market integration (strong form) and implies that the Law of One Price holds contemporaneously. ${ }^{8}$

\section{Data}

The paddy price data were provided by the Information Center for Agriculture and Rural Development (ICARD). ${ }^{9}$ Prices of paddy (and some other agricultural commodities) are collected on Fridays at public markets in sixteen provinces. Based on the weekly data, monthly price series are computed by taking averages. It is worth considering the appropriateness of using monthly series in testing spatial market integration. Luu (2003) argues that average monthly data are inappropriate when analyzing rice market integration in the Mekong River Delta because these prices do not reflect the daily prices on which traders make their arbitrage decisions. However, the weekly price series have several long periods in which prices are constant in almost every market. Such constancy of prices will invalidate a statistical analysis which is based on an assumption of independent and identically distributed innovations that follow a continuous distribution. Moreover, the use of weekly data is problematic due to the need to interpolate numerous missing values. For these reasons we have chosen to analyze the monthly data instead of the weekly data. However, since contemporaneous prices cannot be used both to distinguish regimes and as a dependent variable,

\footnotetext{
${ }^{8}$ If the Law of One Price is not rejected in a regime, the model for that regime reduces to $\Delta p_{1 t}=\Delta p_{2 t}+\delta_{1}^{(s)} \Delta\left(p_{t t-1}-p_{2 t-1}\right)+\alpha^{(s)}\left(p_{t t-1}-p_{2 t-1}-\mu^{(s)}\right)+\phi S_{t}+\varepsilon_{t}$, and this implies that the loading parameter $\alpha^{(s)}$ is no longer of "special interest" for describing the dynamics of price adjustment. ${ }^{9}$ See http://www.agroviet.gov.vn.
}

16 FOI The Spatial Integration of Paddy Markets in Vietnam 
we construct the regime indicators using prices lagged by half a month. ${ }^{10}$ This lag corresponds to the time it typically takes traders to make inter-provincial shipments.

For paddy prices, we have complete monthly data across eight markets from January, 1993 to May, 2006. Four out of the eight markets are located in the Red River Delta (Ha Noi, Bac Ninh, Nam Dinh, and Thai Binh). The other four markets are located in the Mekong River Delta (Can Tho, An Giang, Tien Giang, and Ca Mau). As can be seen in Figure 6, all these provinces cluster round the 1A National Road, which is the main road connecting the North, Centre and South of Vietnam. National roads also connect Ha Noi with Bac Ninh, Nam Dinh and Thai Binh and Can Tho with An Giang and Tien Giang. Given the fact that inflation has changed substantially over the period, we adjust for its effects by deflating nominal paddy prices using the Consumer Price Index into constant January 1993 prices.

In addition to price series, we also need estimates of transfer costs to determine the thresholds used in the estimation of the threshold error correction model defined by equations (4) and (8). Transfer costs represent the total observed costs of moving paddy from one market to another, and include both fixed costs and variable costs elements. Data on these fixed and variable costs were collected through interviews with traders and lorry drivers in Hanoi and Ho Chi Minh City during the summer of 2006. ${ }^{11}$ The fixed cost element comprises loading and unloading costs plus specific trade taxes (where applicable). The variable cost element comprises pure freight costs, which vary with the distance travelled and road conditions, and ad valorem trade taxes. From our interviews with traders, we have estimated the unit cost of transporting one kilogram of paddy over one kilometre. We assume that these unit costs are constant in real terms and do not vary according to the distance between markets. ${ }^{12}$ So to estimate the transportation costs between two markets, we multiply the unit costs of transportation by the distance between markets. Finally, since it is rice rather than paddy which is usually transported between provincial markets, we also adjust transfer costs by the milling ratio between paddy and rice.

\footnotetext{
${ }^{10} \mathrm{We}$ do this by taking an average of the inter-market price spreads at time $t$ and $t$-1. i.e., $\lambda\left(p_{1 t}-p_{2 t}\right)+(1-\lambda)\left(p_{1 t-1}-p_{2 t-1}\right)$ where $\lambda=0.5$. Setting $\lambda$ equal to 0.25 or 0.75 produces similar results.

${ }^{11}$ Our interviews with traders indicate that, due to the transshipment costs involved, very little paddy or rice is transported between provinces using rail or water in Vietnam.

${ }^{12}$ In theory, unit transportation costs should decline with distance travelled. However, our interviews with traders and transporters indicate that this is a very imprecise relationship with freight rates often remaining constant between nearby markets.
} 
Figure 6. Location and Transportation Links between the eight Paddy Markets

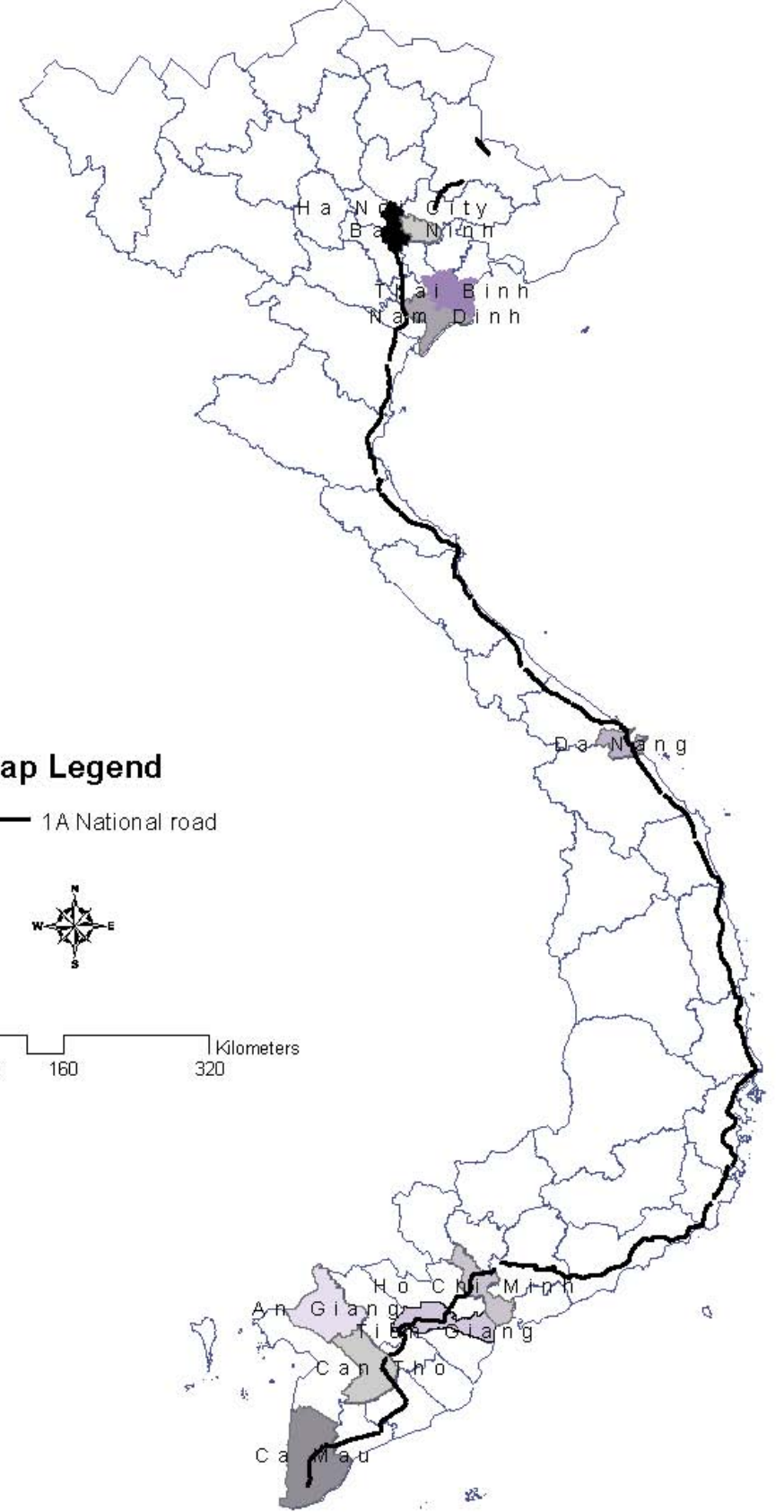

18 FOI The Spatial Integration of Paddy Markets in Vietnam 
Accordingly, our estimates of transfer costs between markets $i$ and $j\left(t c_{i j}\right)$ are based on the following expression:

$$
t c_{i j}=\left(20+0.45 \times D_{i j}\right) / 0.65
$$

where 20 (Dong) is the fixed cost of loading and unloading one kilogram of rice, 0.45 (Dong) is the unit cost of transporting 1 kilogram of paddy for 1 kilometer, $D_{i j}$ is the distance following the main road between market $i$ and market $j$ and 0.65 is the milling (rice-paddy conversion) ratio. ${ }^{13}$

\section{Table 2. Estimated Transfer Costs Between Market Pairs}

\begin{tabular}{|c|c|c|c|}
\hline Market 1 & Market 2 & Distance (km) & Estimated Transfer Cost \\
\hline Ha Noi & Bac Ninh & 25 & 23 \\
\hline Ha Noi & Nam Dinh & 85 & 43 \\
\hline Ha Noi & Thai Binh & 95 & 46 \\
\hline Ha Noi & Can Tho & 1794 & 606 \\
\hline Can Tho & Ha Noi & 1794 & 758 \\
\hline Can Tho & An Giang & 65 & 36 \\
\hline Can Tho & Tien Giang & 115 & 53 \\
\hline Can Tho & Ca Mau & 213 & 85 \\
\hline
\end{tabular}

Notes: The transfer costs are measured in Dong per kg in January 1993 prices.

Table 2 presents our estimated transfer costs between the market pairs in our analysis. To be consistent with the paddy price series, we have deflated our transfer cost estimates to constant January 1993 terms. Within each region (North or South), transfer costs from the main markets in the producing areas to Hanoi and Can Tho account for three to four percent (i.e., VND 36 to 46 per kilogramme) of the median paddy price. We assume that, within regions, transfer costs from market $i$ to market $j$ is the same as from market $j$ to market $i$. However, our discussions with traders suggest that this assumption does not hold between markets in the North and South of Vietnam, since the demand for moving goods from the South to the North is substantially higher than in the opposite direction. Our discussions with traders indicate that the premium on moving produce from the South to the North is approximately 25 percent, so this is added to our estimates of transfer costs between Can Tho and Ha Noi. Once this premium is included, transfer costs between Can Tho and Hanoi account for VND 758 per kilogramme, or almost $70 \%$ of the median paddy price in Can Tho-implying that paddy price levels in the South and North need to differ substantially before it is profitable to ship rice between these regions.

\footnotetext{
${ }^{13}$ Note that unit cost of transportation calculated $(0.45 \mathrm{~kg} / \mathrm{km})$ is very close to the freight rates prescribed for national highways by Vietnam's State Pricing Committee $(0.435 \mathrm{~kg} / \mathrm{km})$ in 2000.
} 


\begin{tabular}{lrrrrr} 
Table 3. & Descriptive Statistics for the Paddy Prices & & \\
Market & Mean & Median & Std. dev. & Min & Max \\
\hline North & & & & & \\
Ha Noi & 1348.89 & 1363.12 & 219.95 & 836.11 & 1934.56 \\
Bac Ninh & 1375.96 & 1350.53 & 232.18 & 1021.99 & 2063.53 \\
Nam Dinh & 1308.69 & 1302.00 & 222.92 & 935.51 & 1930.30 \\
South & & & & & \\
Thai Binh & 1286.03 & 1267.31 & 212.27 & 919.78 & 1862.91 \\
Can Tho & 1090.79 & 1093.13 & 137.32 & 765.33 & 1412.56 \\
An Giang & 1083.93 & 1083.61 & 155.86 & 716.89 & 1487.86 \\
Tien Giang & 1112.76 & 1112.13 & 149.78 & 755.10 & 1560.78 \\
Ca Mau & 1101.36 & 1106.82 & 166.43 & 729.56 & 1668.21 \\
\hline
\end{tabular}

Notes: There are 161 observations in the sample (1993m1-2006m5). Prices are measured in terms of Dong per kg in January 1993 prices.

Table 3 shows means, medians, and other basic statistics of the monthly price series. We note that, on average, prices in the Northern provinces are higher than those in the Southern provinces. Among the eight markets in our sample, An Giang and Can Tho have the lowest paddy prices. This low level of prices may well reflect that An Giang and Can Tho are the largest paddy producers in Vietnam. In contrast, the highest level of prices are in Bac Ninh and Ha Noi in the North. Note that the median prices in Ha Noi, the capital centre, are higher than in nearby Bac Ninh although the reverse is true for mean prices.

We examine the time series properties of the prices by testing for stationarity using Elliott, Rothenberg, and Stock's (1996) modified Dickey-Fuller test. ${ }^{14}$ Table 4 reports the unit root test results using the ERS test with a trend as the dominating deterministic component. The number of lags is chosen using the Schwarz information criterion. All price series in the northern markets have unit roots in levels but not in first differences, hence they are I(1). However, in the southern markets the price series from An Giang, and Tien Giang do not seem to have unit roots when tested at the 5 percent level of significance though they do have unit roots at the 1 percent level. The test statistic for Ca Mau lies on the boundary of accepting or rejecting the unit root at the 1 percent level. Like the North, the null hypothesis of a unit root is rejected for the first differences of the prices in the South. In sum, we conclude that, all the price series are integrated of order 1 .

\footnotetext{
${ }^{14}$ This test follows the augmented Dickey-Fuller procedure, but has better power than the standard ADF-test in small samples (Baum and Sperling, 2001). The ERS test is also known as the DFGLS test.
}

20 FOI The Spatial Integration of Paddy Markets in Vietnam 


\section{Table 4. Unit-Root Tests}

\begin{tabular}{|c|c|c|c|c|}
\hline \multirow[b]{2}{*}{ Market } & \multicolumn{2}{|c|}{----- First differences -------- } & \multicolumn{2}{|c|}{ 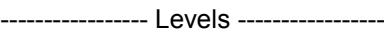 } \\
\hline & Optimal lag & Test statistic & Optimal lag & Test statistic \\
\hline \multicolumn{5}{|l|}{ North } \\
\hline Ha Noi & 1 & -10.31 & 2 & -2.21 \\
\hline Bac Ninh & 1 & -8.42 & 1 & -2.34 \\
\hline Nam Dinh & 1 & -8.91 & 1 & -2.35 \\
\hline Thai Binh & 1 & -8.97 & 1 & -2.34 \\
\hline \multicolumn{5}{|l|}{ South } \\
\hline Can Tho & 4 & -3.06 & 2 & -2.48 \\
\hline An Giang & 1 & -10.13 & 1 & -3.22 \\
\hline Tien Giang & 1 & -9.75 & 1 & -2.96 \\
\hline Ca Mau & 3 & -3.32 & 1 & -3.52 \\
\hline
\end{tabular}

Notes: The test for unit-roots is the Elliot, Rothenberg and Stock (1996) test with seasonal dummies included. The $1 \%, 5 \%$, and $10 \%$ critical values for levels are $-3.51,-2.91$, and -2.63 , respectively. The $1 \%, 5 \%$, and $10 \%$ critical values for first differences are $-2.59,-2.04$, and -1.72 , respectively.

\section{Empirical Results}

In this Section, we apply the sequential approach to testing for market integration discussed in Section 3 to the eight non-stationary paddy price series described above in order to investigate: (i) whether paddy markets in the North and the South of Vietnam are spatially integrated, (ii) if paddy markets within the North and within the South are integrated, and (iii) if price adjustment within regions is stronger (and faster) than between them.

To investigate whether paddy markets in the North and the South of Vietnam are spatially integrated, we choose Ha Noi to represent the North and Can Tho to represent the South. Ha Noi, the capital city, is the second largest city in Vietnam and is located close to the centre of the Red River Delta. Can Tho is the major milling and exporting centre in the Mekong River Delta. ${ }^{15}$ Having tested if Ha Noi and Can Tho are spatially integrated, we then move on to examining whether the other three markets in the North (Bac Ninh, Nam Dinh and Thai Binh) are spatially integrated with Ha Noi. Then we perform similar tests with Can Tho and the other three markets in the South (An Giang, Tien Giang and Ca Mau). Recall that only when market segmentation is rejected and long-run market integration is accepted, do we move on to testing for common dynamics and the Law of One Price.

\footnotetext{
${ }^{15}$ Ho Chi Minh City, the major commercial centre and largest city in Vietnam, would have been an alternative choice for the major centre of demand in the South. However, it is not located in the Mekong River Delta and the paddy price data available for Ho Chi Minh City are very incomplete.
} 


\begin{tabular}{|c|c|c|c|c|c|c|c|c|}
\hline Market pairs & $\begin{array}{l}\text { \# of } \\
\text { thres- } \\
\text { holds }\end{array}$ & Regime & $\begin{array}{l}\text { Regime } \\
\text { Frequen- } \\
\text { cies }\end{array}$ & $\begin{array}{l}\text { Long-run } \\
\text { Integra- } \\
\text { tion }\end{array}$ & $\begin{array}{l}\text { Common } \\
\text { Dynamics }\end{array}$ & $\begin{array}{l}\text { Law of } \\
\text { One Price }\end{array}$ & $\gamma$ & $\alpha$ \\
\hline Ha Noi - Can Tho & 0 & & & A & $\mathrm{R}$ & $\mathrm{R}$ & $\begin{array}{c}0.410 \\
(0.105)\end{array}$ & $\begin{array}{l}-0.149 \\
(0.040)\end{array}$ \\
\hline \multicolumn{9}{|l|}{ North } \\
\hline \multirow[t]{2}{*}{ Ha Noi - Bac Ninh } & \multirow[t]{2}{*}{1} & $\begin{array}{c}\text { Above+ } \\
\text { No-trade }\end{array}$ & 0.50 & A & A & $\mathrm{R}$ & $\begin{array}{c}0.644 \\
(0.073)\end{array}$ & $\begin{array}{l}-1.181 \\
(0.356)\end{array}$ \\
\hline & & Below & 0.50 & A & A & $\mathrm{R}$ & $\begin{array}{c}0.637 \\
(0.082)\end{array}$ & $\begin{array}{l}-0.606 \\
(0.096)\end{array}$ \\
\hline \multirow[t]{3}{*}{ Ha Noi - Nam Dinh } & \multirow[t]{3}{*}{2} & Above & 0.42 & A & A & $\mathrm{R}$ & $\begin{array}{c}0.600 \\
(0.084)\end{array}$ & $\begin{array}{l}-0.437 \\
(0.105)\end{array}$ \\
\hline & & No-trade & 0.37 & A & A & A & $\begin{array}{c}1 \\
(-)\end{array}$ & \\
\hline & & Below & 0.21 & A & A & A & $\begin{array}{l}1 \\
(-)\end{array}$ & \\
\hline \multirow[t]{3}{*}{ Ha Noi - Thai Binh } & \multirow[t]{3}{*}{2} & Above & 0.54 & A & A & $\mathrm{R}$ & $\begin{array}{c}0.495 \\
(0.073)\end{array}$ & $\begin{array}{l}-0.407 \\
(0.088)\end{array}$ \\
\hline & & No-trade & 0.32 & A & A & $\mathrm{R}$ & $\begin{array}{c}0.779 \\
(0.074)\end{array}$ & $\begin{array}{l}-1.394 \\
(0.151)\end{array}$ \\
\hline & & Below & 0.14 & A & A & A & $\begin{array}{c}1 \\
(-)\end{array}$ & \\
\hline \multicolumn{9}{|l|}{ South } \\
\hline \multirow[t]{3}{*}{ Can Tho - An Giang } & \multirow[t]{3}{*}{2} & Above & 0.27 & A & A & $\mathrm{R}$ & $\begin{array}{c}0.733 \\
(0.073)\end{array}$ & $\begin{array}{l}-1.083 \\
(0.175)\end{array}$ \\
\hline & & No-trade & 0.57 & A & A & $\mathrm{R}$ & $\begin{array}{c}0.859 \\
(0.057)\end{array}$ & $\begin{array}{l}-1.357 \\
(0.117)\end{array}$ \\
\hline & & Below & 0.16 & A & $\mathrm{R}$ & $\mathrm{R}$ & $\begin{array}{c}0.868 \\
(0.010)\end{array}$ & $\begin{array}{l}-1.201 \\
(0.158)\end{array}$ \\
\hline \multirow[t]{3}{*}{ Can Tho - Tien Giang } & \multirow[t]{3}{*}{2} & Above & 0.08 & A & A & A & $\begin{array}{c}1 \\
(-)\end{array}$ & \\
\hline & & No-trade & 0.62 & A & A & $\mathrm{R}$ & $\begin{array}{c}0.798 \\
(0.062)\end{array}$ & $\begin{array}{l}-0.587 \\
(0.095)\end{array}$ \\
\hline & & Below & 0.3 & A & A & $\mathrm{R}$ & $\begin{array}{c}0.808 \\
(0.066)\end{array}$ & $\begin{array}{l}-0.947 \\
(0.172)\end{array}$ \\
\hline \multirow[t]{2}{*}{ Can Tho - Ca Mau } & \multirow[t]{2}{*}{2} & Above & 0.06 & A & A & $\mathrm{R}$ & $\begin{array}{c}0.452 \\
(0.200)\end{array}$ & $\begin{array}{l}-0.864 \\
(0.306)\end{array}$ \\
\hline & & No-trade & 0.77 & $\mathrm{R}$ & & & & \\
\hline
\end{tabular}

Notes: $\mathrm{R}$ and $\mathrm{A}$ indicate the null-hypotheses can be rejected and 'accepted' at the $5 \%$ level of significance. Standard errors of the estimated parameters $\gamma$ and $\alpha$ are shown in round brackets.

Table 5 summarizes the test results for all market pairs. ${ }^{16}$ Two thresholds are indicated for all market pairs except for Ha Noi and Can Tho (where no thresholds are detected) and between Ha Noi and Bac Ninh (where there is no statistical difference be-

\footnotetext{
${ }^{16}$ Tables A1 and A2 in the Appendix provide diagnostic tests for our empirical models. In general, the models are well specified as we find no evidence of autocorrelation or regime dependent heteroskedasticity. In addition, as seen from Table A2, the final models have constant parameters, judged by the Nyblom-Hansen test for parameter instability.
}

\section{FOI The Spatial Integration of Paddy Markets in Vietnam}


tween the parameters in the no trade and above threshold regimes). Market segmentation is also strongly rejected for all market pairs, except for Can Tho and Ca Mau, implying that paddy prices in the demand centers are influenced by paddy prices in the markets in the producing areas.

Figure 7. Cross Plot of Ha Noi and Can Tho and Time Series Plot of the Intermarket Price Spread with Thresholds given by Estimated Transfer Costs
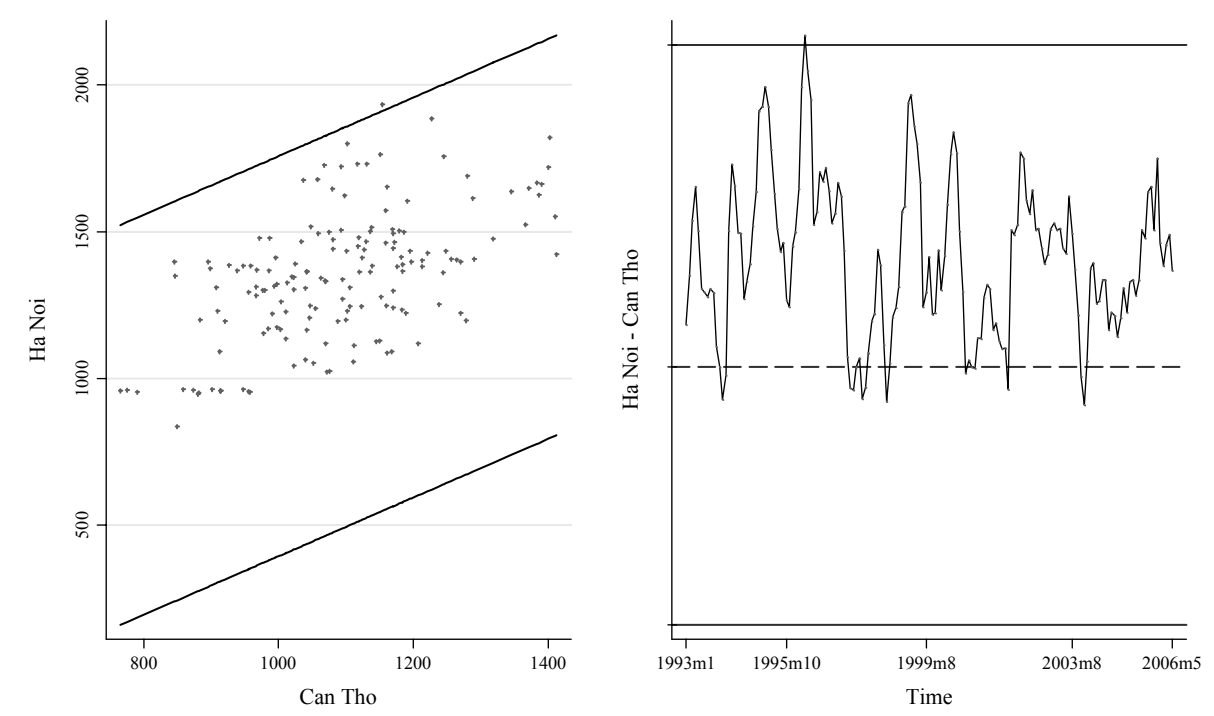

Source: Drawn by the authors using price data from the Information Center for Agriculture and Rural Development

The finding of no thresholds for Ha Noi and Can Tho requires further comment, as these are the two most important demand centres in the Red River and Mekong River deltas. The absence of a threshold between these markets implies that there is a linear relationship between paddy prices in Ha Noi and Can Tho. As can been seen from the time series plot of price differences on the right hand side of Figure 7, the intermarket price spread only exceeds estimated transfer costs in 1 of our 161 observations. Under such circumstances one would not expect to observe a high correlation between paddy price changes in Ha Noi and Can Tho, and this is born out by the disparate cross plot of prices on the left-hand side of Figure 7. It is also reflected in the coefficient of 0.41 on contemporaneous price changes $(\gamma)$ in Can Tho in the unrestricted linear error correction model. Furthermore, the loading coefficient $(\alpha)$ on the 
lagged inter-market price spread indicates that the speed of price adjustment between Ha Noi and Can Tho is rather slow. Put differently, transfer costs between Ha Noi and Can Tho (which are 1,790 kms apart) are sufficiently high to make trade between the two markets unprofitable virtually all of the time. We can therefore conclude that paddy markets in Ha Noi and Can Tho are only weakly integrated which, in turn, suggests there is low integration between paddy and rice markets in the North and South of Vietnam. ${ }^{17}$

In contrast to Ha Noi and Can Tho, thresholds are indicated for all market pairs within the North and within the South of Vietnam. In general, we find two-threshold models, in accordance with the theory. However, for Ha Noi and Bac Ninh, the two geographically closest markets in our series we find no statistical significant difference between the parameters in the regime above the threshold (when the price in Ha Noi is greater than the price in Bac Ninh plus transfer costs) and the no-trade regime. This may reflect Bac Ninh's role as satellite town to Hanoi, with millers and wholesalers shipping to either Hanoi or Bac Ninh but little paddy or rice being traded between the two markets. Hence for this market pair, a one threshold model is estimated with strong co-movement of prices indicated by the $\gamma$ coefficients (of 0.644 and 0.637 ) in the two regimes.

Given the results about the number of thresholds we move on to test the hypothesis of long-run market integration for each regime in turn. Long-run integration, which corresponds to a one-unit change in the price in one market eventually translating into a one-unit price change in the other market, occurs in all regimes in all markets in the North and in all regimes in two of the three markets in the South. The exception is the market pair Can Tho - Ca Mau for which long run integration is rejected both in the no-trade regime and in the below regime (when the paddy price in Ca Mau exceeds the paddy price in Can Tho plus the transfer costs). For these two markets, long run integration cannot be rejected in the upper regime, although the number of observations is very small in that regime, making us reluctant to draw strong conclusions for this test.

Only when long-run market integration is indicated do we test for common dynamics and the Law of One Price using the restricted version of the threshold error correction model. Generally, for thresholds and market pairs for which long-run integration is

\footnotetext{
${ }^{17}$ Recall that the price series used for these tests are for ordinary paddy, so there may still be trade in high quality ('fancy') rice between the South and North of Vietnam.
}

24 FOI The Spatial Integration of Paddy Markets in Vietnam 
indicated, common dynamics are also found. ${ }^{18}$ The finding of a common dynamics shows that all necessary information for predicting the future price is contained in the inter-market price spread (weak-form market efficiency).

The Law of One Price is, however, firmly rejected for most market pairs. ${ }^{19}$ This is not surprising as the form of the Law of One Price which is being tested requires that: (i) price changes in the two markets move together on a one-for-one basis within a single period and, (ii) that the common factor restriction also holds. As can be seen from the last but one column of Table 5, the $\gamma$ coefficients between contemporaneous prices changes for these regimes and market pairs are all between 0.41 and 0.87 . This is indicative of reasonably strong but far from one-for-one co-movement of paddy prices. For most market pairs, the $\gamma$ coefficients exceed 0.6 when the inter-market price spread is above the upper or below the lower threshold. From this we may conclude that, when prices between markets are above or below their threshold levels, at least 60 percent of price changes are transmitted between markets within a month.

The final column of Table 5 shows the loading coefficients $(\alpha)$ from the restricted error correction models. As expected, all the loading coefficients are negative showing that the inter-market price spreads will converge to their long-run equilibrium values. The absolute sizes of the coefficients indicate very rapid 'corrections' in some markets. In particular in the South we find that the inter-market price spreads returns to the no-trade regime within the following month. In addition, the absolute size of the loading coefficient is much smaller for Ha Noi and Can Tho than for market pairs within the North and within the South. This suggests that prices co-move more strongly when the threshold band is narrow. Put differently, when transfer costs do not prevent trade, spatial arbitrage brings price differentials back to their thresholds quickly. This is confirmed by the time series plots in Figure 8, which shows fairly rapid reversion of the price spreads whenever spreads exceeds the transfer costs.

\footnotetext{
${ }^{18}$ Here the exception is the lower regime in the Can Tho - An Giang market in which common dynamics is rejected with a $p$-value of 0.04 .

${ }^{19}$ When the Law of One Price is not rejected it is often in regimes with a relatively low frequency, such as the lower regime in the Ha Noi - Thai Binh market and the upper regime in the Can Tho Tien Giang market. However, we find the Law of One Price to hold in two regimes in the Ha Noi Nam Dinh market suggesting a close integration of this market pair.
} 

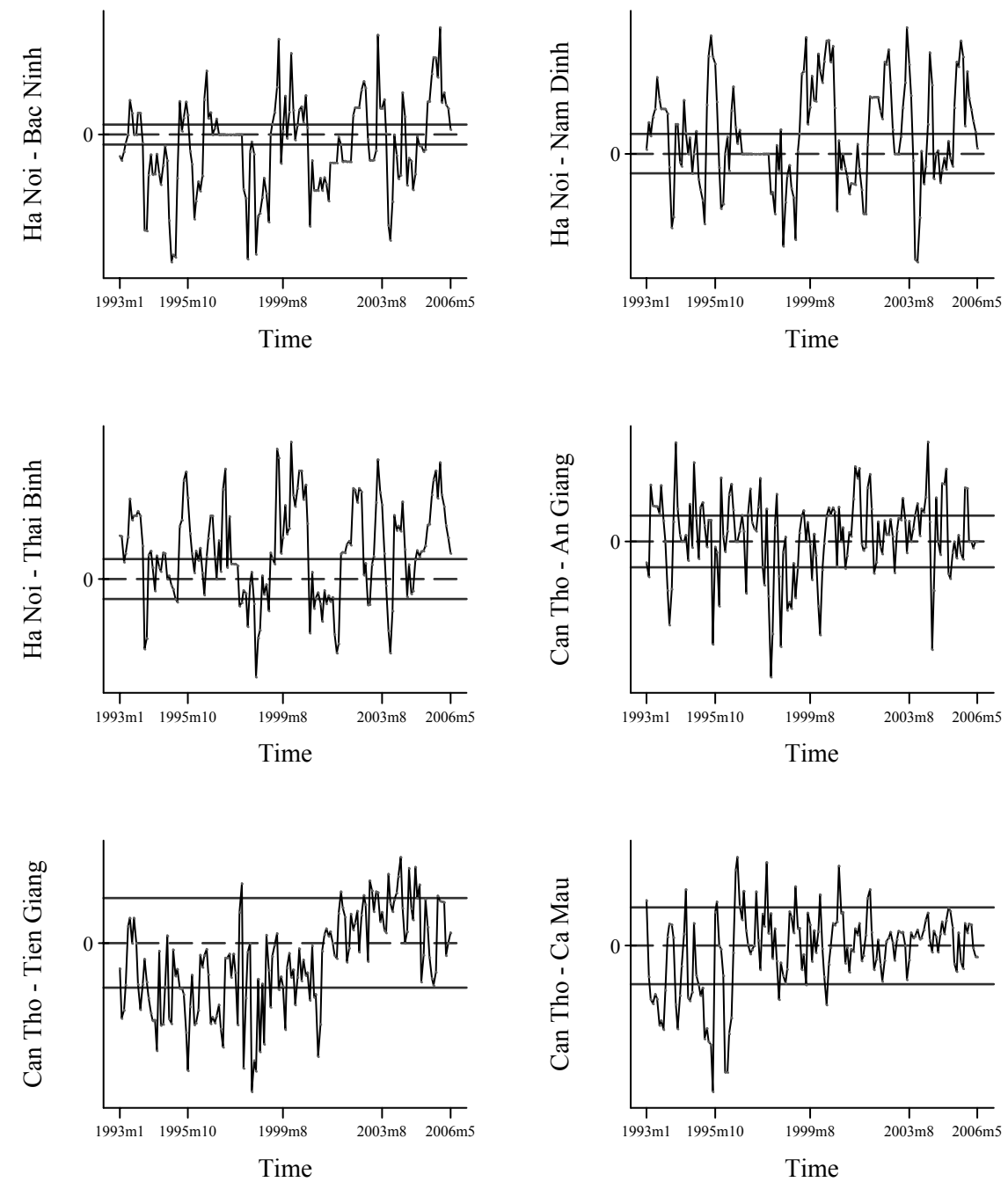

Source: Drawn by the authors using price data from

the Information Center for Agriculture and Rural Development

Taken together, our sequential tests for market integration show weak evidence of market integration between paddy markets in the North and South of Vietnam, but

26 FOI The Spatial Integration of Paddy Markets in Vietnam 
stronger evidence of spatial market integration within the North and within the South. ${ }^{20}$ While there is evidence of thresholds and long-run integration for most market pairs, the strict version of the Law of One Price does not hold in general even when the price difference between markets exceed the upper or lower thresholds. Nonetheless, when price spreads are above or below the relevant thresholds, a large fraction of the price changes are transmitted between paddy markets within a very short period of time. The extent and speed of price transmission is generally faster in paddy markets located in the South.

\section{Conclusion and Policy Implications}

There has been very little research on food market integration in Vietnam. This paper aims to fill this gap by focusing on the spatial integration of paddy markets in the Red River and Mekong River deltas. The empirical model developed uses estimates of transfer costs to generalize the well-known Ravallion model to allow for the possibility of threshold effects. A sequential testing strategy is developed which progressively tests for market segmentation, the number of thresholds, long-run market integration, common dynamics and (the strict version of) the Law of One Price within an errorcorrection framework.

We find weak evidence of market integration between paddy markets in the North and South of Vietnam and an absence of threshold effects. However, there is evidence of both threshold effects and stronger forms of spatial market integration for paddy markets within the North and within the South. Specifically, convergence towards the relevant thresholds and informational efficiency hold for most market pairs, with at least 60 percent of price changes being transmitted between markets within one month whenever price spreads exceeds their upper or lower thresholds. The extent and speed of price transmission within regional paddy markets is generally faster in the South than the North of Vietnam. However, the instantaneous version of the Law of One Price, which requires full price adjustment occur within a month, only holds for a few regimes and market pairs.

\footnotetext{
${ }^{20}$ These results resonate with those of Moser, Barrett and Minten (2001) in Madagascar, who found little integration of rice markets at the national level-due to prohibitively high transport costswhile rice markets at the sub-regional level were fairly well integrated. Moser, Barrett and Minten's conclusion that intra-seasonal trade reversals occurred in $63 \%$ of Malagasy communes is also similar to our finding of two-thresholds for most market pairs within North and South Vietnam. Note that both Madagascar and Vietnam are geographically large and long countries.
} 
The policy implications of these results are twofold. First, since there is limited evidence of integration between paddy markets in the North and South of Vietnam, national level policies cannot be relied upon to stabilize or support paddy prices. Instead, the Government objectives of stabilizing and supporting farmgate paddy prices need to be designed and implemented with the specific production, consumption and marketing characteristics of northern and southern Vietnam in mind. In addition, as noted in Newberry and Stiglitz (1981) classic text, it is also essential that the benefits and costs of price stabilization are carefully assessed. Second, since there is evidence of market integration within the Red River and Mekong River deltas, paddy markets within these regions can be relied upon to transmit price signals between deficit and surplus areas relatively well. Furthermore, since the speed and extent of price transmission is relatively rapid within the North and within the South of Vietnam, the private sector trade can be relied upon to transfer rice and paddy between markets in an efficient manner. If, however, large demand-supply imbalances were to emerge between the North and South, transfer costs are likely to prevent private-sector trade taking place and the public sector might need to intervene to ensure adequate supplies in the short-term. Such interventions would, however, need to be implemented in a consistent and market friendly way to avoid destabilizing and distorting an essentially well integrated and competitive paddy marketing system.

28 FOI The Spatial Integration of Paddy Markets in Vietnam 


\section{References}

Alexander, C. and Wyeth, J. (1994), "Cointegration and market integration: an application to the Indonesian rice market", Journal of Development Studies, 30: 303328.

Barker, R., Ringler, C., Nguyen, M.T., and Rosegrant, M. (2004) "Macro policies and investment priorities for irrigated agriculture in Vietnam", Comprehensive Assessment Research Report 6, International Water Management Institute.

Baulch, B. (1997) "Transfer costs, spatial arbitrage, and testing for food market integration”, American Journal of Agricultural Economics, 79: 477-487.

Baum, C. and Sperling, R. (2001). "DFGLS: Stata module to compute DickeyFuller/GLS unit root tests", Statistical Software Components S410001, Boston College, Department of Economics.

Benjamin, D. and Brandt, L. (2004), "Agriculture and income distribution in rural Vietnam under economic reforms: a tale of two regions" in Glewwe, P., Agrawal, N., and Dollar, D. (eds), Economic Growth, Poverty and Household Welfare in Vietnam, World Bank Regional and Sectoral Studies, Washington DC: World Bank

Centre for Agricultural Policy (2007), Personal Communication, 24 August 2007

Dawson, P. J. and Dey, P. (2002), "Testing for the Law of One Price: rice market integration in Bangladesh", Journal of International Development, 14: 473-484.

Elliott, G., Rothenberg, T. and Stock, J. (1996), "Efficient tests for an autoregressive unit root", Econometrica, 64: 813-836.

FAOSTAT Data (2006), http://faostat.fao.org/faostat/collections?subset=agriculture , last accessed February 2006.

Fackler, P. and Goodwin, B. (2001), 'Spatial price analysis', in Gardner, B. and Rausser, G. (eds), Handbook of Agricultural Economics, Volume 1, Elsevier 
Goodfrey, L. G. (1988), Misspecification Tests in Econometrics: The Lagrange Multiplier Principle and Other Approaches, Econometric Society Monographs No. 16, Cambridge: Cambridge University Press.

Goodwin, B. and Piggott, N. (1990), "Spatial market integration in the presence of threshold effects", American Journal of Agricultural Economics, 83(2): 302317.

GSO (2006), Statistical Yearbook of Vietnam 2005, Statistical Publishing House

Hansen, B. E. (1992), "Testing for parameter instability in linear models", Journal of Policy Modeling, 14: 517-533.

Hansen, B.E. (1996), "Inference when a nuisance parameter is not identified under the null hypothesis", Econometrica 64: 413-430.

Hansen, B. E. (1997), "Inference in TAR models", Studies in Nonlinear Dynamics and Econometrics 2: 1-14.

Isard, P. (1977), "How far can we push the 'Law of One Price?", American Economic Review, 67(5): 942-48.

Jones, W. (1968), "The structure of staple food marketing in Nigeria as revealed by rice analysis”, Food Research Institute Studies, 8(2): 95-124.

Lele, U. (1967), "Market integration: a study of sorghum prices in Western India", Journal of Farm Economics, 49(1): 149-59.

Luu, Thanh Duc Hai (2003), "The organization of the liberalized rice market in Vietnam”, PhD thesis, University of Groningen, Netherlands.

Meyer, J. (2004), "Measuring market integration in the presence of transaction costs - a threshold vector error correction approach". Agricultural Economics, 31: 327-334.

Minot, N. and F. Goletti (1999), "Rice market liberalization and poverty in Vietnam", IFPRI Research Report 114, Washington, DC: International Food Policy Research Institute.

30 FOI The Spatial Integration of Paddy Markets in Vietnam 
Moser, C., Barrett, C. and Minten, B. (2001), 'Spatial integration of rice markets in Madagascar', Mimeo, Department of Economics, Western Michigan University, Department of Agricultural Econmics, Cornell University

Newberry, D and Stiglitz, J., (1981), The Theory of Commodity Price Stabilization: A Study in the Economics of Risk. Oxford: Oxford University Press

Nyblom, J (1989) "Testing for the constancy of parameters over time", Journal of the American Statistical Association, 84: 223-230.

Ravallion, M. (1986), “Testing market integration", American Journal of Agricultural Economics, 68:102-09.

Richardson, D (1978), "Some empirical evidence on commodity arbitrage and the Law of One Price", Journal of International Economics, 8: 341-51.

Sarno, L., Taylor, M. and Chowdhury, I. (2004) "Nonlinear dynamics in the deviations from the Law of One Price: a broad-based empirical study", Journal of International Money and Finance, 23: 1-25.

Sexton, R., Kling, C. and Carmen, H. (1991), "Market Integration, Efficiency of Arbitrage and Imperfect Competition: Methodology and an Application to U.S. Celery", American Journal of Agricultural Economics, 17(2): 568-580.

Tran, T.U. (2002) 'The impact of the green revolution on rice production in Vietnam', Paper presented to the Foundation for Advanced Studies on International Development, Tokyo, Dec 8-10. 


\section{Appendix: Model Diagnostics}

In this Appendix we report some diagnostic test statistics for the market integration models. The main questions we address are the assumption of $\operatorname{iid}\left(0, \sigma^{2}\right)$ innovations across the regimes and the assumption of regime independent additive seasonal components. In addition, we report tests of parameter constancy to give support to main test results in Table 5. The diagnostic tests are based on the model in equation (8) in which we impose long run integration when it is accepted (see Table 5). Hence, the estimated short run parameters, $\gamma^{(s)}, \delta_{1}{ }^{(s)}, \delta_{2}{ }^{(s)}$, and $\alpha^{(s)}$ are unrestricted in all regimes.

Table A1 reports $p$-values of three test statistics for each of the markets within the Red River and Mekong River deltas. The first statistic is the Breuch-Goodfrey test of first-order autocorrelation in the innovations. (See e.g. Goodfrey, 1988). In general, the null-hypothesis of lack of first-order autocorrelation cannot be rejected although the hypothesis is marginally rejected at the $1 \%$ level of significance for the Ha Noi Thai Binh market.

The second statistic is the Breuch-Pagan test for heteroskedasticity in the innovations, in which we use the version of the test that does not assume normality of the innovations (i.e., we use $T R^{2}$ where $T$ is the number of observations and $R^{2}$ is the un-centred $R$-squared from the auxiliary regression). We test specifically for differences in the innovation variance across the regimes and, as seen from Table A1, we cannot reject the hypothesis that the innovation variance is constant, although the hypothesis is marginally rejected for the Ha Noi - Nam Dinh market.

Based on the tests for autocorrelation and regime dependent heteroskedasticity, we do not find statistical evidence against the assumption of $\operatorname{iid}\left(0, \sigma^{2}\right)$ innovations.

\section{Table A1. Model Diagnostics for the Six Local Markets}

\begin{tabular}{lrrrrrr} 
& $\begin{array}{c}\text { Ha Noi - } \\
\text { Bac Ninh }\end{array}$ & $\begin{array}{r}\text { Ha Noi - } \\
\text { Nam Dinh }\end{array}$ & $\begin{array}{c}\text { Ha Noi - } \\
\text { Thai Binh }\end{array}$ & $\begin{array}{r}\text { Can Tho- An } \\
\text { Giang }\end{array}$ & $\begin{array}{r}\text { Can Tho - } \\
\text { Tien Giang }\end{array}$ & $\begin{array}{r}\text { Can Tho - } \\
\text { Ca Mau }\end{array}$ \\
\hline Autocorrelation & 0.76 & 0.73 & 0.01 & 0.14 & 0.61 & 0.84 \\
Heteroskedasticity & 0.13 & 0.02 & 0.57 & 0.16 & 0.28 & 0.16 \\
Common Seasonals & 0.24 & 0.22 & 0.34 & 0.18 & 0.30 & 0.85 \\
\hline
\end{tabular}

Notes: The figures reported in the table are $p$-values

32 FOI The Spatial Integration of Paddy Markets in Vietnam 
Tabel A2. Nyblom-Hansen Tests of parameter constancy

\begin{tabular}{|c|c|c|c|c|c|c|}
\hline & & $\delta_{\text {। }}$ & $\delta_{2}$ & $\gamma$ & $\alpha$ & $\sigma$ \\
\hline Ha Noi - Can Tho & & 0.145 & 0.268 & 0.186 & 0.268 & 0.098 \\
\hline $\begin{array}{l}\text { North } \\
\text { Ha Noi - Bach Ninh }\end{array}$ & $\begin{array}{r}\text { Above+Inside } \\
\text { Below }\end{array}$ & $\begin{array}{l}0.142 \\
0.098\end{array}$ & $\begin{array}{l}0.124 \\
0.158\end{array}$ & $\begin{array}{l}0.049 \\
0.101\end{array}$ & $\begin{array}{l}0.126 \\
0.344\end{array}$ & 0.217 \\
\hline Ha Noi - Nam Dinh & $\begin{array}{l}\text { Above } \\
\text { Inside } \\
\text { Below }\end{array}$ & $\begin{array}{l}0.120 \\
0.048 \\
0.073\end{array}$ & $\begin{array}{l}0.076 \\
0.034 \\
0.203\end{array}$ & $\begin{array}{l}0.245 \\
0.236 \\
0.040\end{array}$ & $\begin{array}{l}0.033 \\
0.052 \\
0.102\end{array}$ & $0.592^{*}$ \\
\hline Ha Noi - Thai Binh & $\begin{array}{l}\text { Above } \\
\text { Inside } \\
\text { Below }\end{array}$ & $\begin{array}{l}0.141 \\
0.121 \\
0.067\end{array}$ & $\begin{array}{l}0.261 \\
0.046 \\
0.086\end{array}$ & $\begin{array}{l}0.111 \\
0.067 \\
0.075\end{array}$ & $\begin{array}{l}0.124 \\
0.260 \\
0.034\end{array}$ & 0.309 \\
\hline $\begin{array}{l}\text { South } \\
\text { Can Tho - An Giang }\end{array}$ & $\begin{array}{l}\text { Above } \\
\text { Inside } \\
\text { Below }\end{array}$ & $\begin{array}{r}0.105 \\
0.674^{*} \\
0.033\end{array}$ & $\begin{array}{l}0.046 \\
0.192 \\
0.091\end{array}$ & $\begin{array}{l}0.126 \\
0.250 \\
0.055\end{array}$ & $\begin{array}{l}0.181 \\
0.161 \\
0.083\end{array}$ & 0.113 \\
\hline Can Tho - Tien Giang & $\begin{array}{l}\text { Above } \\
\text { Inside } \\
\text { Below }\end{array}$ & $\begin{array}{r}0.016 \\
0.459^{* *} \\
0.056\end{array}$ & $\begin{array}{l}0.033 \\
0.273 \\
0.034\end{array}$ & $\begin{array}{l}0.018 \\
0.058 \\
0.036\end{array}$ & $\begin{array}{l}0.010 \\
0.337 \\
0.060\end{array}$ & 0.100 \\
\hline Can Tho - Ca Mau & $\begin{array}{l}\text { Above } \\
\text { Inside } \\
\text { Below }\end{array}$ & $\begin{array}{l}0.088 \\
0.278 \\
0.079\end{array}$ & $\begin{array}{l}0.022 \\
0.098 \\
0.017\end{array}$ & $\begin{array}{l}0.049 \\
0.213 \\
0.031\end{array}$ & $\begin{array}{l}0.052 \\
0.214 \\
0.045\end{array}$ & 0.323 \\
\hline
\end{tabular}

Notes: * Significant at $5 \%$; ${ }^{* *}$ at $10 \%$. The critical values for the parameter stability tests are $0.748(1 \%)$ $0.470(5 \%)$ and $0.353(10 \%)$, see Hansen (1992).

Next, we turn to the second auxiliary assumption: common seasonality across regimes. This assumption is mainly imposed to preserve degrees of freedom and it is straight forward to augment the regression models to include regime specific additive seasonality. The last row in Table A1 reports tests of the joint significance of regime specific seasonal dummies. For all markets we find statistical support for the hypothesis of common additive seasonal components.

In Table A2 we report Nyblom-Hansen test statistics for parameter constancy (Nyblom, 1989; Hansen, 1992). The tests are Lagrange Multiplier statistics based on the null-hypothesis of constant parameters against the alternative that the parameters follow a random walk. The limiting distribution of the test statistics is non-standard, but critical values are reported in Hansen (1992). Table A2 shows that we cannot reject the assumption of constant parameters: at the $5 \%$ level of significance, we only reject the null-hypothesis for two out of 79 parameters, while constancy is not rejected for any of the parameters at the $1 \%$ level.

Overall, based on the suite of diagnostic tests we conclude that our threshold regression models appear well specified. 
Working Papers

Institute of Food and Resource Economics

13/07 September 2007 Le Dang Trung Tran Ngo Minh Tam

Bob Baulch

Henrik Hansen

12/07 August 2007 Wusheng Yu

11/07 June 2007

10/07 June 2007

09/07 June 2007

Mogens Lund

08/07 May 2007

07/07 May 2007

06/07 May 2007

05/07 Maj 2007
Kimmie Graber-Lützhøft Derek Baker

Svend Rasmussen

Jørgen Dejgård Jensen Anja Skadkær Møller

Derek Baker Karen Hamann

Derek Baker Jens Abildtrup Anders Hedetoft René Kusier

Jørgen Dejgård Jensen
The Spatial Integration of Paddy Markets in Vietnam

Schemes for aggregating preferential tariffs in agriculture, export volume effects and African LDCs

Muligheder, trusler og forventninger i dansk fødevareindustri

Agricultural Sector Modelling - A Micro-based Approach based on Mathematical Programming

Exploiting the Cointegration Properties of US Pork related Markets: The Emergence of a U.S. Demand for Pork as an Input

Vertical price transmission in the Danish food marketing chain

Innovation and the policy environment

Findings from a workshop with meat industry firms in Skive

Role of regional and rural developement policy in supporting small-scale agribusiness in remote areas

Analyse af tre forskellige scenarier for afgiftsændringer på fødevarer

34 FOI The Spatial Integration of Paddy Markets in Vietnam 
04/07 March 2007 Hans Grinsted Jensen Kenneth Baltzer Ronald A. Babula Søren E. Frandsen

03/07 March 2007 Svend Rasmussen

02/07 Februar 2007

Kenneth Baltzer Søren E. Frandsen Hans G. Jensen

01/07 Januar 2007

Lill Andersen Ronald A. Babula Helene Hartmann Martin M. Rasmussen

11/06 December 2006 Lars Otto

10/06 December 2006 Lars Otto

09/06 Oktober 2006 Johannes Sauer Arisbe MendozaEscalante

08/06 August 2006

07/06 Maj 2006

06/06 Maj 2006
Johannes Sauer Jesper Graversen Tim Park

Solange Sotelo Niels Tvedegaard

Johannes Sauer

Jacob Ladenburg Søren Bøye Olsen
The Economy-Wide Impact of Multilateral NAMA Tariff Reductions: A Global and Danish Perspective

Optimising Production using the State-Contingent Approach versus the EV Approach

European Free Trade Areas as an alternative to Doha - Impacts of US, Russian and Chinese FTAs

A Vector Autoregression Model of Danish Markets for Pork, Chicken, and Beef

GRO modellen: Grise, Risiko og Økonomi. Datagrundlag

GRO modellen: Grise, Risiko og Økonomi. Teoretiske grundlag

Schultz's Hypothesis Revisited Small Scale Joint - Production in the Eastern Amazon

Recent Productivity Developments and Technical Change in Danish Organic Farming - Stagnation?

Prices and Species Deversity Stochastic Modelling of Environmental Efficiency

Starting Point Anchoring Effects in Choice Experiments 
05/06 Marts 2006

Svend Rasmussen

04/06 Marts 2006

03/06 Januar 2006

02/06 Januar 2006

01/06 Januar 2006
Red. Johannes Christensen

Jacob Ladenburg

Johannes Sauer

B. Balint

Johannes Sauer
Optimizing Production under Uncertainty.

Generalization of the State-

Contingent Approach and Comparison with the EV Model

Fremtidens biogasfællesanlæg. Nye anlægskoncepter og økonomisk potentiale

Attitudes towards Wind Power Development in Denmark Romanian Maize - Distorted Prices and Producer Efficiency

Economic Theory and Econometric Practice: Parametric Efficiency Analysis

36 FOI The Spatial Integration of Paddy Markets in Vietnam 